\title{
Relationship between oxidative stress and diabetic osteopenia in premenopausal rats
}

\author{
Valéria Morgiana Gualberto Duarte ${ }^{1}$, Alanna de Sousa Rodrigues² ${ }^{2}$ Luciana Augusto de Rezende $^{3}$, \\ Ana Maria de Oliveira Ramos ${ }^{4}$, Rodrigo Medeiros de Souza ${ }^{5}$, Francisco Paulo Freire Neto ${ }^{6}$, Aldo da \\ Cunha Medeiros ${ }^{6}$, José Brandão Neto ${ }^{6}$, Maria das Graças Almeida ${ }^{7}$, Adriana Augusto de Rezende ${ }^{7, *}$
}

\author{
${ }^{1}$ Department of Pharmacy, School of Pharmacy, State University of Paraiba, Paraiba, Brazil, ${ }^{2}$ Clinical Analysis Laboratory, \\ Hospital São José, Ceará, Brazil, ${ }^{3}$ Department of Chemistry, School of Chemistry, University of Ribeirão Preto, São Paulo, \\ Brazil, ${ }^{4}$ Department of Clinical Pathology, School of Medicine, Federal University of Rio Grande do Norte, Rio Grande \\ do Norte, Brazil, ${ }^{5}$ Nursing School, Federal University of Acre, Acre, Brazil, ${ }^{6}$ Department of Medicine, School of Medicine, \\ Federal University of Rio Grande do Norte, Rio Grande do Norte, Brazil, ${ }^{7}$ Department of Clinical Analysis and Toxicology, \\ Federal University of Rio Grande do Norte, Rio Grande do Norte, Brazil
}

\begin{abstract}
The relationship between lipid peroxidation, antioxidant defense and diabetic osteopenia remains unclear. This study evaluated the relationship among lipid peroxidation index, antioxidant defense parameters and bone metabolism in a premenopausal diabetic model using measures including thiobarbituric acidreactive substances concentration (TBARS) and reduced glutathione (GSH) content in brain homogenates, histomorphometric analysis, biomechanical testing and bone mineral density (BMD). Female Wistar rats with regular estrous cycle were divided into two groups: Group 1: control rats $(n=15)$ and Group 2: diabetic rats $(n=15)$. Diabetes was induced by alloxan and confirmed by glycemia $\geq 250 \mathrm{mg} / \mathrm{dL}$. The lipid peroxidation index, measured by TBARS concentration, showed a significant increase $(\mathrm{p}<0.05)$ in diabetic animals in comparison to control animals. However, the antioxidant parameter measured by GSH content, was significantly lower $(\mathrm{p}<0.05)$ in diabetic animals. Histomorphometric analysis showed a significant increase $(\mathrm{p}<0.05)$ in femoral trabecular separation together with a significant decrease $(\mathrm{p}<0.05)$ in trabecular thickness, and reduced trabecular bone volume in diabetic rats. Moreover, biomechanical testing and BMD values were significantly lower $(\mathrm{p}<0.05)$ in the diabetic group. Thus, our results demonstrated that increased lipid peroxidation and altered antioxidant defense could be related to the development of oxidative stress and diabetic osteopenia in premenopausal rats.
\end{abstract}

Uniterms: Oxidative stress. Lipid peroxidation. Diabetes mellitus. Diabetic osteopenia/experimental study.

A relação entre peroxidação lipídica, defesa antioxidante e osteopenia diabética permanece obscura. Este estudo avaliou a associação entre índice de peroxidação lipídica, parâmetro de defesa antioxidante e metabolismo ósseo em um modelo diabético pré-menopausa através de medidas como a concentração de substâncias reativas ao ácido tiobarbitúrico (SRAT) e conteúdo de glutationa reduzida (GSH) no homogenato cerebral, análises histomorfométricas, teste biomecânico e densidade mineral óssea (DMO). Ratos Wistar fêmeas com ciclo estral regular foram distribuídos em dois grupos: Grupo 1 - ratas controle $(\mathrm{n}=15)$ e Grupo 2 - ratas diabéticas $(\mathrm{n}=15)$. O diabetes foi induzido pela aloxana e confirmado pela glicemia $\geq 250 \mathrm{mg} / \mathrm{dL}$. O índice de peroxidação lipídica, medido pela concentração de SRAT, demonstrou um aumento significativo $(\mathrm{p}<0.05)$ nos animais diabéticos, em relação aos animais controle. Entretanto, o parâmetro de defesa antioxidante, mensurado pelo conteúdo de GSH, foi reduzido significativamente $(\mathrm{p}<0.05)$ nos animais diabéticos. As análises histomorfométricas mostraram um aumento significativo $(\mathrm{p}<0.05)$ da separação trabecular do fêmur, associado à diminuição significativa da espessura trabecular $(\mathrm{p}<0.05)$ e volume ósseo trabecular reduzido nas ratas diabéticas. Além disso, o teste biomecânico,

*Correspondence: A. A. Rezende. Departamento de Análises Clínicas e Toxicológicas, Centro de Ciências da Saúde, Universidade Federal do Rio Grande do Norte, 59010-180 - Natal - RN, Brazil. E-mail: adrirezende@yahoo.com 
medido pela força máxima, e valores de DMO foram reduzidos significativamente $(\mathrm{p}<0.05)$ no grupo diabético. Dessa maneira, nossos resultados demonstraram que a peroxidação lipídica aumentada e defesa antioxidante modificada podem estar relacionadas ao desenvolvimento do estresse oxidativo e osteopenia diabética em ratas pré-menopausadas.

Unitermos: Estresse oxidativo. Peroxidação lipídica. Diabetes mellitus. Osteopenia diabética/estudo experimental.

\section{INTRODUCTION}

Bone is formed and reabsorbed continuously, starting in the embryo and continuing throughout adult life. Bone homeostasis is regulated by the balance between bone matrix formation by osteoblasts and resorption by osteoclasts (Rho et al., 2004; Boyce, Xing, 2008). In general, disturbances in inflammatory cytokines and hormones cause an imbalance between osteoblasts and osteoclast activities and can result in skeletal osteopenia and osteoporosis (McCabe, 2007).

There is considerable interest in discovering the factors involved in the control of osteoclasts, and thus osteoporosis, such as the receptor activator of NF- $\kappa B$ (RANK), RANK ligand (RANKL), and osteoprotegerin (OPG) (Rasmusse et al., 2006; Wada et al., 2006). The binding of RANKL to its receptor RANK provides the crucial signal to drive osteoclast development from haematopoietic progenitor cells as well as to activate mature osteoclasts. OPG negatively regulates RANKL binding to RANK and therefore inhibits bone turnover by osteoclasts (Boyce, Xing, 2008). Since increased osteoclast activity is observed in patients with osteoporosis, metastasis or rheumatoid arthritis, the RANK-RANKL-OPG axis appears to be the most relevant therapeutic target for all bone diseases (Kearns et al., 2008).

Resorption events have been linked to numerous factors other than cytokines and hormones, such as growth factors and reactive oxygen species (ROS) formation either in the bone microenvironment or in the osteoclastic precursors of the monocyte-macrophage lineage (Bai et al., 2004; Thrailkill et al., 2005b). Over the last decade, evidence has accumulated of ROS participation in bone resorption, with a direct contribution of osteoclasts generating high concentrations of superoxide anion (O2-) and hydrogen peroxide (H2O2) (Muthusami et al., 2005; Bai et al., 2006). However, the mechanisms by which ROS participate in accelerating the destruction of calcified tissue and hence bone resorption have not been fully explained (Muthusami et al., 2005; Ding et al., 2006). Moreover, the effect of ROS on osteoblastic function remains unclear (Ding et al., 2006). It has been demonstrated that osteo- blasts produce antioxidants such as glutathione peroxidase (GPx) to protect against ROS, but they also produce tumor necrosis factor- $\alpha$ (TNF- $\alpha$ ), which is involved in bone resorption (Isomura et al., 2004; Janssens et al., 2005). Any loss of osteoblastic activity increases osteoclastic activity or osteocyte death by necrosis or apoptosis. This phenomenon could lead to osteoporosis, characteristic of lower bone mineral density (BMD), and render bone weaker and more likely to fracture (Janssens et al., 2005).

In addition, several risk factors for osteoporosis, such as diabetes mellitus (Ding et al., 2006; Léger et al., 2006) and estrogen deficiency (Godsland, 2005; Muthusami et al., 2005) are associated with increased oxidative stress. In diabetes mellitus, persistent hyperglycemia may cause oxidative stress induced by a variety of mechanisms including glucose autoxidation and accelerated glycation reaction, with the formation of glucose-derived advanced glycosylation end products (AGEs), which in turn catalyze lipid peroxidation (Valko et al., 2007). Moreover, there is increased carbonyl stress (Kume et al., 2005), polyol pathway (Oyama et al., 2006) and protein kinase C-dependent activation (Kume et al., 2005). In this sense, increased malondialdehyde concentration (MDA), both in patients (Martìn-Gallán et al., 2003; Tan et al., 2004; Valko et al., 2007) and diabetic animals (Stoppa et al., 2006), has been reported in plasma, erythrocytes, total blood and diverse tissues such as brain, liver, kidney and heart.

There is also evidence that hyperglycemia may reduce antioxidant defense mechanisms by altering antioxidant enzymes, impairing glutathione metabolism, and lowering concentrations of glutathione and vitamins C, E, A and D (Rahimi et al., 2005; Stoppa et al., 2006). Persistent hyperglycemia increases polyol pathway flux, as well as ROS generation rates and AGEs formation, leading to increased GSH oxidation (Oyama et al., 2006). Thus, the association between increased oxidative stress and lower antioxidant defense has an important role in the pathogenesis of diabetic osteopenia (Yamagishi et al., 2005; Ding et al., 2006). Recently, results from our laboratory have demonstrated that supplementation with antioxidants, such as Vitamin E, decreased oxidative stress and markers of lipid peroxidation, and also increased GSH content, representing a prevention 
and therapeutic effect on bone loss. These results supported the vitamin's role as a nutritional and pharmacologic tool in the prevention of osteoporosis.

Considering that our previous report also showed progressive bone loss similar to that which occurs in premenopausal women with advanced diabetes (Duarte et al., 2005), we suggest that the altered redox balance could contribute to the development of diabetic osteopenia. To test this hypothesis, we assessed the relationship between lipid peroxidation, antioxidant defense parameters and bone metabolism in a premenopausal diabetic model without insulin treatment. This was based on thiobarbituric acid-reactive substances (TBARS) and reduced glutathione (GSH) concentrations in the brain associated with histomorphometric analyses, biomechanical testing and bone mineral density of the femora, for 120 days after the onset of experimental diabetes.

\section{MATERIALS AND METHODS}

\section{Animals}

Adult female Wistar rats weighing $200 \pm 20 \mathrm{~g}$ with a regular estrous cycle were obtained from the Animal House of the Health Sciences Center of the Federal University of Rio Grande do Norte, Natal, Brazil. The animals were handled in accordance with the standards of the institutional ethics committee of the University Hospital Onofre Lopes - UFRN and the Revised Guide for the Care and Use of Laboratory Animals (National Research Council, 1996). Daily determination of estrous cycle phases was performed by the previously described vaginal smear method (Duarte et al., 2005). During the experimental period, the animals were housed in polypropylene cages under hygienic conditions in the departmental animal house. They were subjected to a $12 \mathrm{~h}: 12 \mathrm{~h}$ light:dark cycle and constant temperature $\left(22^{\circ} \mathrm{C}-24^{\circ} \mathrm{C}\right)$ and humidity $(50 \%-60 \%)$. The animals had free access to water and to a standard rat diet (Purina, São Paulo, Brazil). Thirty rats were randomly allocated to 2 experimental groups (15 animals/group) as follows: (1) the control group, normal rats treated with vehicle sterile saline without alloxan; (2) the diabetic group, alloxan-induced diabetic rats without insulin treatment. The animals were sacrificed by cervical dislocation on days 1 and 5 after the induction, and on days 45,75 and 120 after the onset of experimental diabetes. Three rats were used in both groups for each experimentation period.

\section{Induction of diabetes}

Experimental diabetes was induced in the animals by a single intraperitoneal injection of the pancreatic $\beta$-cell toxin alloxan monohydrate (Sigma Chemical Co., Madrid, Spain) dissolved fresh in sterile saline ( $0.9 \%$ sodium chloride), at a dose of $120 \mathrm{mg} / \mathrm{kg}$ body weight. This dose was determined after performing three consecutive pilot experiments to define and standardize the dose for the induction and maintenance of diabetes mellitus in the model. All pilot experiments were carried out in accordance with the regulations for research involving animals (National Research Council, 1996), as well as the previous publication (Duarte et al., 2005). Equal volumes of vehicle were injected into the control rats. On day 0 , i.e., 5 th day after induction, blood was collected by tail bleeding and glycemia assayed by a glucose-oxidase method using a glucometer (Advantage-Boehringer Mannheim, Roche, Indianapolis, USA) and compatible reactive test strips. Animals with blood glucose concentrations $250 \mathrm{mg} / \mathrm{dL}$ were considered to be diabetic. The blood glucose concentrations were monitored fortnightly by capillary glycemia throughout the study to determine the hyperglycemic state of the rats. Moreover, clinical signs of diabetes such as polyphagia, polydipsia, polyuria and body weight loss were also observed. The control group injected with saline without alloxan maintained normal blood glucose concentrations. After each experimental period, rats were weighed and killed, and a blood sample was obtained from the abdominal aorta. To avoid any possible daily cyclic variations in the measurements, the animals were killed between 7:00 and 9:00 am. Serum glucose concentration was determined using a commercial kit (BioSystems Reagents and Instruments, Barcelona, Catalunya, Spain) with an RA-50 spectrophotometer (Chemistry System Bayer Diagnostic, Dublin, Belfast, Ireland). Whereas experimental work involved the determination of parameters related to oxidative stress, the animals were not submitted to fasting on the day of sacrifice, avoiding the consequent generation of reactive species. Accordingly, several studies in the literature reinforce this approach (Ohkuwa et al., 1995; Çinar et al., 2001). The body weight evolution of the animals was monitored throughout the 120 days after onset of diabetes, on day 0 and at 15-day intervals.

\section{Preparation of brain tissue homogenates}

The brain was perfused with ice-cold $0.9 \%$ saline in situ, removed and the frontal lobe divided into two parts, which were weighed, washed and homogenized with specific buffers. The homogenates were centrifuged at $1000 \mathrm{~g}$ for $4 \mathrm{~min}$ at $4{ }^{\circ} \mathrm{C}$ (Multispeed Centrifuge PK 121R Refrigerated version; ALC, Cologno Monzese, MI, 
Italy). The lipid peroxidation index in brain homogenate was determined by the concentration of thiobarbituric acid reacting substances (TBARS) and was expressed in terms of TBARS (nmol/g tissue) (Bird, Draper, 1984). In addition, the antioxidant parameter was also determined in brain homogenate by reduced GSH content and expressed as mmol GSH/L-1 (Beutler et al., 1963). The concentrations of TBARS and reduced GSH content were measured with an RA-50 spectrophotometer (Chemistry System Bayer Diagnostic, Dublin, Belfast, Ireland). These assays were performed in triplicate in diabetic and control rats 1 and 5 days after induction, and 45 and 75 days after onset of experimental diabetes.

\section{Histology and histomorphometric analysis}

The left femora of each animal, at 1 and 5 days after induction and 45, 75 and 120 days after onset of experimental diabetes, was fixed in $10 \%$ formalin, processed after immersion in $7.5 \%$ nitric acid and embedded in paraffin following standard procedures. Longitudinal sections ( 5 to 7 microns) were stained with hematoxylin and eosin. Sections were selected for analysis to represent a central gap location. Histomorphometric parameters of the left femora were the result of the means of four measurements of trabecular separation (Tb.Sp, $\mu \mathrm{m}$ ) and trabecular thickness (Tb. Th, $\mu \mathrm{m}$ ) and trabecular bone volume (BV/TV, \%) obtained from the metadiaphyseal region, using a Nikon Lobophot microscope equipped with a $10 \mathrm{X}$ magnification ocular lens (Nikon, Tokyo, Japan). The results were reported in $\mathrm{mm}$ (Duarte et al., 2005). To analyze the percentage of the area occupied by trabecular bone and intertrabecular bone marrow, photomicrographs were taken of the femoral metadiaphyseal region at 200X magnification. These photographs were analyzed using Photo Studio Version 2.0 SE (Tiling 3D grid, medium grid size) by the Delesse principle (Duarte et al., 2005). All parameters complied with the guidelines of the nomenclature committee of the American Society of Bone and Mineral Research (Hamada et al., 2007).

\section{Biomechanical testing}

The bone mechanical property was evaluated using the right femoral of each animal, at 1 and 5 days after induction, and 45 and 120 days after onset of experimental diabetes, for a maximum load test representing the maximum compressive force applied until fracture. The biomechanical parameter was tested using an Instron mechanical testing apparatus (Model 4444; Instron Corpo- ration, Canton, MA, USA), and the compressive loading speed used in all tests was $10 \mathrm{~mm} / \mathrm{min}$. The results were reported as Maximum Load (N) (Reddy et al., 2001).

\section{Bone mineral densities}

The BMDs of the total and metadiaphyseal bone regions of the right femoral were scanned at 1 and 5 days after induction, and 45 and 120 days after onset of experimental diabetes. These densitometries were measured by DXA, using a Lunar DPX (System no. 6647, software version 3.6z; Lunar Radiation Corp., Madison, WI, USA) adapted for measuring small animals. All scans were performed by a licensed radiology technician, using the same instrument as previously described (Duarte et al., 2005).

\section{Statistical analysis}

Statistical analyses of the data were performed using Statistica software, Version 6.0 (StatSoft Inc., Tulsa, OK, USA). The trabecular bone volume value is expressed in percentages. All other values are reported as mean \pm SD. Statistical significance was determined by 1-way analysis of variance (ANOVA), which was followed by Tukey's test. The significance levels were defined by $p<0.05$.

\section{RESULTS}

\section{Blood glucose concentrations and body weight}

Mean changes in blood glucose concentrations and body weight of the control and diabetic groups are shown in Table I. As expected, a significant increase in blood glucose was observed in the diabetic rats compared to control rats throughout the experimental period $(p<$ $0.05)$. Moreover, the diabetic rats also showed other signs and symptoms commonly associated with type 1 diabetes mellitus, such as polyphagia, polydipsia and polyuria. Body weight was significantly reduced in alloxan-induced rats compared to control rats on days 75 and 120 after the onset of diabetes $(p<0.05)$. Thus, these data show that hyperglycemia in the diabetic group was consistent and not transitory.

\section{Oxidant and antioxidant analysis}

The oxidant and antioxidant analyses of brain homogenate are shown in Table I. TBARS concentration, an important marker of lipid peroxidation, was slightly elevated at the onset of experimental diabetes, and incre- 
ased in a time-dependent manner $(p<0.05)$. On day 75 , diabetic rats showed a statistically significant increase in TBARS concentration compared to control rats. A statistically significant decrease was observed in the reduced GSH content in diabetic animals compared to control animals during the same experimental period $(p<0.05)$. No correlation was found between glycemia and TBARS concentrations or between glycemia and GSH content. These results may indicate increased lipid peroxidation and altered antioxidant defense.

\section{Histomorphometry measurements}

Histomorphometric changes are shown in Table II. A progressive loss of bone mass was observed in the femoral histomorphometry of diabetic rats compared to control rats throughout the experimentation period (Figures 1, 2 and 3). Accordingly, the femoral trabecular separation (Tb.Sp, $\mu \mathrm{m})$ was significantly increased $(\mathrm{p}<0.05)$ and femoral trabecular thickness ( $\mathrm{Tb}$. Th, $\mu \mathrm{m}$ ) was significantly decreased $(\mathrm{p}<0.05)$ in diabetic rats compared to the control group. In addition, these histomorphometric changes were also accompanied by a decrease $(\mathrm{p}<0.05)$ in trabecular bone volume $(\mathrm{BV} / \mathrm{TV}, \%)$ in diabetic rats during the same period. No correlations were found between glycemia and histomorphometry measurements. Taken together, these results demonstrated low bone turnover resulting from an imbalance between bone formation and resorption in diabetic premenopausal rats.

\section{Biomechanical properties}

Table II shows the extent of alterations in the biomechanical properties of the diabetic femoral. The maximum femoral load was significantly lower (by about $25 \%$ ) in alloxan-induced rats than in the control rats on day 120 after onset of diabetes $(p<0.05)$. No correlation was found between glycemia and maximum femoral load. This data supports the observation that the experimental diabetic state is associated with mechanical bone deterioration, resulting in bones with altered biomechanical properties similar to that shown in patients with diabetes mellitus.

\section{Bone mineral densities}

The BMDs of the control and diabetic groups are shown in Table II. The BMD of the femora was significantly lower in the diabetic group throughout the experimental study compared with the control group $(p<0.05)$. Furthermore, the decrease in BMD of the femora was greater in the metadiaphyseal region than in the total region in diabetic rats. No correlations were found between glycemia and BMD measurements. These results also demonstrated a progressive decrease of bone mass in the diabetic premenopausal rats.

\section{DISCUSSION}

The existence of osteopenia and osteoporosis has been increasingly recognized as a complication of diabe-

TABLE I - Glucose, body weight, oxidant and antioxidant parameters in the brain of premenopausal Wistar rats

\begin{tabular}{|c|c|c|c|c|c|c|c|c|c|c|}
\hline \multirow[t]{2}{*}{ Variables } & \multicolumn{5}{|c|}{ CONTROL (days) } & \multicolumn{5}{|c|}{ DIABETIC (days) } \\
\hline & 1 & 5 & 45 & 75 & 120 & 1 & 5 & 45 & 75 & 120 \\
\hline $\begin{array}{l}\text { Blood } \\
\text { glucose } \\
(\mathrm{mg} / \mathrm{dL})\end{array}$ & $146.8 \pm 13.7$ & $145.6 \pm 14.1$ & $148.3 \pm 25.5$ & $196.7 \pm 13.2$ & $190.5 \pm 31.0$ & $503.8 \pm 51.5^{*}$ & $324.8 \pm 5.6^{*}$ & $352.6 \pm 26.1^{*}$ & $294.2 \pm 38.3^{*}$ & $543.2 \pm 31.6^{*}$ \\
\hline $\begin{array}{l}\text { Body } \\
\text { Weight } \\
\text { (g) }\end{array}$ & $210 \pm 17.0$ & $207 \pm 11.0$ & $210 \pm 7.0$ & $233 \pm 5.0$ & $215 \pm 5.0$ & $190 \pm 10$ & $198 \pm 7$ & $190 \pm 10$ & $180 \pm 10^{*}$ & $180 \pm 5^{*}$ \\
\hline $\begin{array}{l}\text { TBARS } \\
\text { (nmol/g } \\
\text { tissue) }\end{array}$ & $56.1 \pm 4.9$ & - & $57.1 \pm 5.0$ & $124.3 \pm 11.1^{*}$ & - & $63.5 \pm 8.9$ & - & $62.1 \pm 7.6$ & $167.6 \pm 16.3^{* *}$ & - \\
\hline $\begin{array}{l}\mathrm{GSH} \\
\left(\mathrm{GSH} / \mathrm{L}^{-1}\right)\end{array}$ & $1.2 \pm 0.0$ & - & $1.0 \pm 0.1$ & $1.1 \pm 0.1$ & - & $1.4 \pm 0.0$ & - & $1.2 \pm 0.1$ & $0.81 \pm 0.0^{* *}$ & - \\
\hline
\end{tabular}

Data are expressed as mean \pm SD ( $\mathrm{n}=15$ rats in both groups). Three rats were used in both groups for each experimental period (days 1 and 5 after induction with alloxan and days 45, 75 and 120 after the onset of experimental diabetes). TBARS indicate thiobarbituric acid reacting substances; GSH, reduced glutathione.

" $p<.05$ by 1 -way-ANOVA followed by Tukey's test when values are compared with control group

${ }^{* *} p<.05$ by 1 -way-ANOVA followed by Tukey's test when values are compared with control and diabetic groups 
TABLE II - Histomorphometry measurements, biomechanical testing and bone mineral density in femoral of premenopausal Wistar rats

\begin{tabular}{|c|c|c|c|c|c|c|c|c|c|c|}
\hline \multirow[t]{2}{*}{ Variables } & \multicolumn{5}{|c|}{ CONTROL (days) } & \multicolumn{5}{|c|}{ DIABETIC (days) } \\
\hline & 1 & 5 & 45 & 75 & 120 & 1 & 5 & 45 & 75 & 120 \\
\hline $\begin{array}{l}\text { Trabecular } \\
\text { distance } \\
(\mathrm{mm})\end{array}$ & $\begin{array}{c}0.10 \pm \\
0.02\end{array}$ & $\begin{array}{c}0.14 \pm \\
0.00\end{array}$ & $\begin{array}{c}0.16 \pm \\
0.01\end{array}$ & $\begin{array}{c}0.17 \pm \\
0.02\end{array}$ & $\begin{array}{l}0.22 \pm \quad 0 \\
0.07\end{array}$ & $0.11 \pm 0.02$ & $\begin{array}{c}0.23 \pm \\
0.04\end{array}$ & $\begin{array}{l}0.36 \pm \\
0.02\end{array}$ & $\begin{array}{c}0.46 \pm \\
0.08\end{array}$ & $\begin{array}{c}0.52 \pm \\
0.06^{*}\end{array}$ \\
\hline $\begin{array}{l}\text { Trabecular } \\
\text { thickness } \\
(\mathrm{mm})\end{array}$ & $\begin{array}{c}0.10 \pm \\
0.01\end{array}$ & $\begin{array}{c}0.09 \pm \\
0.02\end{array}$ & $\begin{array}{c}0.09 \pm \\
0.00\end{array}$ & $\begin{array}{c}0.09 \pm \\
0.00\end{array}$ & $\begin{array}{c}0.09 \pm \\
0.00\end{array}$ & $\begin{array}{c}0.07 \pm \\
0.01\end{array}$ & $\begin{array}{l}0.05 \pm \\
0.00^{* *}\end{array}$ & $\begin{array}{l}0.04 \pm \\
0.01^{* *}\end{array}$ & $\begin{array}{l}0.03 \pm \\
0.00^{* *}\end{array}$ & $\begin{array}{l}0.03 \pm \\
0.01^{* *}\end{array}$ \\
\hline $\begin{array}{l}\text { Trabecular } \\
\text { bone volume } \\
(\%)\end{array}$ & 78.0 & 77.7 & 60.0 & 55.2 & 49.0 & 66.0 & 64.3 & 23.0 & 22.2 & 20.0 \\
\hline $\begin{array}{l}\text { Maximum } \\
\operatorname{load}(\mathrm{N})\end{array}$ & $\begin{array}{c}862.66 \pm \\
1.15\end{array}$ & - & $\begin{array}{l}818.33 \pm \\
11.15\end{array}$ & - & $\begin{array}{c}821.33 \pm \\
7.09\end{array}$ & $\begin{array}{c}834.33 \pm \\
0.57\end{array}$ & - & $\begin{array}{c}673.00 \pm \\
36.51^{* *}\end{array}$ & - & $\begin{array}{c}606.66 \pm \\
18.00^{* *}\end{array}$ \\
\hline \multicolumn{11}{|l|}{ BMD } \\
\hline $\begin{array}{l}\text { Metadiaphyseal } \\
\left(\mathrm{g} / \mathrm{cm}^{2}\right)\end{array}$ & $\begin{array}{c}0.12 \pm \\
0.00\end{array}$ & - & $\begin{array}{c}0.13 \pm \\
0.01\end{array}$ & - & $0.11 \pm 0.01$ & $\begin{array}{l}0.15 \pm \\
0.02\end{array}$ & - & $\begin{array}{l}0.09 \pm \\
0.01^{* *}\end{array}$ & - & $\begin{array}{l}0.08 \pm \\
0.00^{* *}\end{array}$ \\
\hline $\begin{array}{l}\text { Total } \\
\left(\mathrm{g} / \mathrm{cm}^{2}\right)\end{array}$ & $\begin{array}{c}0.15 \pm \\
0.01\end{array}$ & - & $\begin{array}{c}0.13 \pm \\
0.00\end{array}$ & - & $\begin{array}{c}0.13 \pm \\
0.01\end{array}$ & $\begin{array}{c}0.17 \pm \\
0.02\end{array}$ & - & $\begin{array}{c}0.14 \pm \\
0.01\end{array}$ & - & $\begin{array}{c}0.10 \pm \\
0.08^{*}\end{array}$ \\
\hline
\end{tabular}

Trabecular bone volume value is given as percentage. All other data are reported as mean \pm SD ( $\mathrm{n}=15$ rats in both groups). Three rats were used in both groups for each experimental period (days 1 and 5 after induction with alloxan and days 45, 75 and 120 after the onset of experimental diabetes). BMD indicates bone mineral density. BMD was measured by dual-energy X-ray absorptiometry method (DXA).

${ }^{*} p<.05$ by 1 -way-ANOVA followed by Tukey's test when values are compared with control and diabetic groups

${ }^{* *} p<.05$ by 1 -way-ANOVA followed by Tukey's test when values are compared with control group

tes mellitus. However, the timing of the onset of diabetic bone disease remains somewhat controversial (Kemink et al., 2000; Thrailkill et al., 2005a; Duarte et al., 2005). In this context, many authors believe that diabetes-induced oxidative stress is a factor in the evolution and progression of diabetic complications (Ding et al., 2006; Hamada et al., 2007). Thus, oxidative stress has been suggested as a common pathway linking diverse mechanisms to the pathogenesis of this disorder. We selected alloxan-induced diabetic female rats with a regular estrous cycle as a useful model for investigating the interrelationship between lipid peroxidation, antioxidant defense, type 1diabetes mellitus and premenopausal bone loss. This model previously showed progressive bone loss similar to that which occurs in premenopausal women with advanced diabetes (Duarte et al., 2005).

According to the World Health Organization (WHO) menopause is defined as the permanent interruption of spontaneous menstruation for a period of 12 months, a result of reduced ovarian follicular activity. Menopause is preceded by the menopausal transition, also known as perimenopause, which is characterized by irregular menstrual cycles or a prolonged period of amenorrhea of more than 12 months. The period preceding the perimenopause, where there are regular menstrual cycles, is known as premenopause or reproductive period (WHO, 1996; Blake, 2006; Lund, 2008).

The female sexual cycle has characteristics similar to the estrous cycle of other species, including rodents. In rats, the cycle is characterized as proestrus, estrus, metestrus and diestrus. The ovulation occurs from the beginning of proestrus to the end of estrus. From the onset of sexual maturity up to the age of 12 months, the mean cycle length in the female rat is 4 days, and this short cycle length makes the rat an ideal animal for investigation of changes occurring during the reproductive cycle (Papanicolaou, 1933).

The phases of the estrous cycle are identified by histological examination of vaginal smears, since this constitutes an accurate, sensitive and fast method allowing phase identification without sacrificing the animal (Martins et al., 2005). In this study, the model used showed maintenance of a regular estrous cycle, determined by vaginal smears (Duarte et al., 2005; Martins et al., 2005).

The regular estrous cycle of rats is consistent with the condition of regular menstruation of the pre-meno- 

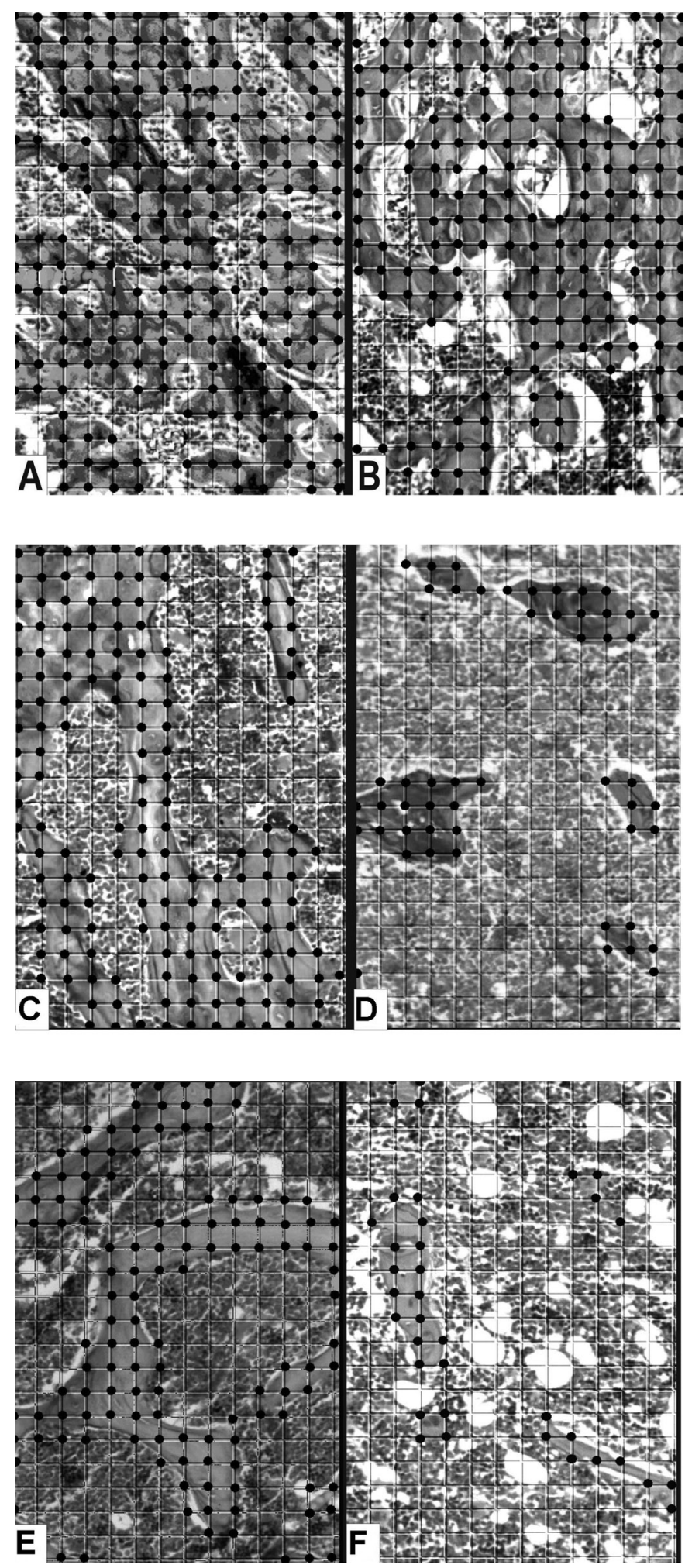

FIGURE 1- Simultaneous demonstration of trabecular separation, trabecular thickness, and trabecular bone volume in femur sections of control rats (A, C, E) and diabetic rats (B, D, F), on day 5 (A, B) after induction of experimental diabetes, on day $45(\mathrm{C}, \mathrm{E})$ and day 120 post-onset of experimental diabetes. $\mathrm{H} \& \mathrm{E}, \mathrm{X} 200$. pausal women. Thus, this model may be used to represent pre-menopausal osteopenia. In this context, it is important report that during commencement of menopause the first cycles can become irregular, are sometimes anovulatory, and finally disappear. This condition was not observed in the animal model used.

In preliminary experiments, to exclude potential secondary effects of alloxan treatment, so-called alloxan toxicity, we also examined an insulin-treated diabetic group. Insulin treatment largely restored general histomorphometric measurements, reduced BMD and biomarkers of bone metabolism, indicating that the osteopenia in alloxan-induced diabetic rats was strictly related to the diabetic state (data not shown). In this context, the degree of glycemic control (which is directly related to insulin sufficiency) has been shown to strongly correlate with bone integrity in various diabetic models (Thrailkill et al., 2005 b.). However, this study was not aimed at insulin treatment, but evaluated animals in a state of chronic hyperglycemia. Thus, we observed marked hyperglycemia, weight loss and common clinical signs, such as polyphagia, polydipsia and polyuria as previously described (Duarte et al., 2005). During the experimental period, it was clear that diabetic animals (blood glucose $\geq 250 \mathrm{mg} / \mathrm{dL}$ ) had a higher intake of food and water. This group also had a higher urine volume excreted over a period of 24 hours.

Although several studies have examined diabetic osteopenia in experimental models (Thrailkill et al., 2005a; Hamada et al., 2007), the majority of these involved postmenopausal female rats. Furthermore, although the relationship between oxidative stress and diabetic osteopenia has been shown by previous studies (Ding et al., 2006; Hamada et al., 2007), the effect of altered redox balance on osteoblast activity contributing to the onset of diabetic osteopenia remains unclear.

Our results showed a significant increase in TBARS concentration in the brain homogenate of diabetic rats as early as 24 hours after the onset of diabetes, continuing throughout the entire 75-day study, which was considered sufficient evidence to demonstrate a significant change and the close involvement of the stress condition in the development of osteopenia. These results support the association of diabetes mellitus with increased lipid peroxidation. Although TBARS were not directly measured in cartilage and bone, the results obtained for brain homogenate suggest that TBARS values for skeletal tissues would be higher in diabetic rats compared with control rats during the experimental period. A number of studies have reported the suitability of brain homogenates as an assay system for measuring both oxidative damage and antioxidant activity, since the brain is vulnerable to oxidative 
damage because its membrane lipids are rich in polyunsaturated fatty acids (Santos et al., 2000; Damasceno et al., 2002; Rio et al., 2005). Moreover, it has been reported that the brain contains low levels of antioxidants such as glutathione (GSH) and vitamin $\mathrm{E}$ due to their exhaustion during AGEs detoxification produced by cell membrane lipid peroxidation (Santos et al., 2000; Damasceno et al., 2002). In addition, osteoblasts have appreciable amounts of polyunsaturated fatty acids and hence are highly susceptible to oxidative stress. Therefore, altered antioxidant defense may induce the predisposition of osteoblasts to oxidation and inhibit their activity, resulting in diminished rates of protein synthesis (Arjmandi et al., 2002).

There is also experimental evidence that hyperglycemia may disrupt natural antioxidant defense mechanisms with marked depletion of GSH content, the most prevalent low-molecular weight peptide antioxidant in cells (Cay et al., 2001; Arjmandi et al., 2006) and in patients (MartìnGallán et al., 2003; Rahimi et al., 2005). Our results also showed significantly decreased GSH content in the brain, reflecting the marked increased in lipid peroxidation in experimental advanced diabetes. In this sense, the combination of increased concentration of oxidable substrates and decreased efficiency of detoxification pathways may cause an increase in glycosylation and lipoxidation of tissue proteins, contributing to the development of diabetic complications such as osteopenia and osteoporosis. Previous results in our laboratory showed that supplementation with antioxidants, such as vitamin $\mathrm{E}$, decreased oxidative stress and lipid peroxidation markers and increased GSH content, thus alleviating diabetic osteopenia. These results support the association between oxidative stress and diabetes mellitus complications and the beneficial effects of antioxidants in the management of diabetic osteopenia.

Bone histomorphometry and biomechanical modifications are important factors related to the risk of fracture, given that increased morbidity in orthopedic patients with diabetes is well documented (Suzuki et al., 2004; Thrailkill et al., 2005a). In the current study, our histomorphometric analyses showed significant progressive femoral bone loss in premenopausal diabetic rats as compared to controls rats. Our results also demonstrated that diabetes profoundly affected the histological integrity of the bone, due to alterations such as increase in trabecular separation together with decreases in trabecular thickness and trabecular bone volume that were linearly correlated with the duration and severity of this disorder. Thus, we demonstrated a state of low bone turnover resulting from an imbalance between bone formation and resorption in the animal model used. There is also evidence that diabetes mellitus leads to decreased bone integrity by significant reductions in maximum compressive load, deformation at maximum load and energy absorption capacity of diabetic bone compared to controls (Reddy et al., 2001). Consistent with these reports, our biomechanical analyses indicated that diabetes state affected femoral biomechanical integrity by a significant progressive reduction in comprehensive maximum load in diabetic bone. Therefore, our results once again support the association between diabetes, increased lipid peroxidation and decreased GSH content in the development of bone histomorphometry and biomechanical changes in a premenopausal diabetic model.

DXA has been the predominant technology used to evaluate trabecular bone mass loss both in animal models (Fukuharu et al., 2000; Duarte et al., 2005) and in diabetic patients (Bridges et al., 2005; Léger et al., 2006). In the present study, our results showed a significant decrease in femoral diabetic BMD values, measured by DXA, confirming that the evolution time of diabetes has a deleterious effect on the metabolically active trabecular bone of premenopausal rats. Recently, several clinical investigations also demonstrated that premenopausal women with type 1 diabetes mellitus show significantly lower femoral neck BMD than that of healthy individuals (Hadjidakis et al., 2006). Whereas the objective of this study was to evaluate the relationship between lipid peroxidation index, antioxidant defense and bone metabolism, with emphasis on histomorphometric analysis, biomechanical testing and BMD, there is no serum biochemical analysis associated to bone and mineral metabolism. However, according to a previous publication (Duarte et al., 2005), a significant reduction in serum calcium concentration was observed in this animal model compared to controls. Serum phosphorus and magnesium concentrations did not differ between diabetic and control animals.

Additionally, with the advent of molecular studies, sequence variants in the vitamin D receptor (VDR), collagen 1 alpha 1 chain (Col1A1), estrogen receptor, estrogen receptor alpha (ESR1), OPG, IL-6 and LDL- receptor-related protein 5 (LRP5) genes were all found to be significantly associated with differences in BMD and/or fracture risk in multiple replication studies (Arko et al., 2005; Ferrari, Rizzoli, 2005). Moreover, these investigations indicate an interaction between bone mineral density and/or osteoporotic fractures and their association with complex diseases, including diabetes mellitus, hypertension, coronary heart disease, cancer, arthritis and other common medical conditions (Ferrari, Rizzoli, 2005). These findings also suggest that these gene variants may represent common genetic susceptibility factors exerting pleiotropic effects during the aging process (Ferrari, Rizzoli, 2005).

Thus, identification of osteoporosis risk factors, 
and subsequently of those individuals at highest risk of multiple related disorders with increased oxidative stress, may prompt prevention strategies able to improve global health and optimize medical expenditure in diabetic and/ or aging populations.

\section{CONCLUSIONS}

We demonstrated the relationship between lipid peroxidation, antioxidant defense and diabetic osteopenia in premenopausal rats. The results of this work show that increased lipid peroxidation and altered antioxidant defense may be the key events for developing oxidative stress, suggesting a role of oxidative stress in the pathogenesis of diabetic osteopenia in premenopausal rats. Further investigations will be required to determine the timing of the onset and the role that oxidative stress plays in the progression of diabetic bone disease. Clinical studies are needed to screen and monitor diabetic osteopenia in premenopausal women and to implement preventive or therapeutic interventions, as appropriate.

\section{ACKNOWLEDGMENTS}

This study was supported by grants from CNPq, PIBIC and UNAERP. We thank Luis Fernando Malvestiti, PhD Manoel Sousa Neto and Alberto Ferraz for their valuable cooperation.

\section{REFERENCES}

ARJMANDI, B.H.; JUMA, S.; BEHARKA, A.; BAPNA, M.S.; AKHTER, M.; MEYDANI, S.N. Vitamin E improves bone quality in the aged but not young adult male mice. J. Nutr. Biochem., v.13, n.9, p.543-549, 2002.

ARKO, B.; PREZELJ, J.; KOCIJANCIC, A.; KOMEL, R.; MARC, J. Association of the osteoprotogerin gene polymorphisms with bone mineral density in postmenopausal women. Maturitas, v.51, n.3, p.270-279, 2005.

BAI, X.; LU, D.; BAI, J.; ZHENG, H.; KE, Z.; LI, X.; LUO, S. Oxidative stress inhibits osteoblastic differentiation of bone cells by ERK and NF-kB. Biochem. Biophys. Res. Commun., v.314, n.1, p.197-207, 2004.

BEUTLER, E.; DURON, O.; KELLY, B.M. Improved method for the determination of blood glutathione. J. Lab. Clin. Med., v.61, p.882-888, 1963.
BIRD, R.D.; DRAPER, A.H. Comparative studies on different methods of malondyaldehyde determination. Methods Enzymol., v.105, p.299-305, 1984.

BLAKE, J. Menopause: evidence-based practice. Best Pract. Res. Cl. Ob., v.20, n.6, p.799-839, 2006.

BOYCE, B.F.; XING, L. Functions of RANKL/RANK/OPG in bone modeling and remodeling. Arch. Biochem. Biophys., v.473, n.2, p.139-146, 2008.

BRIDGES, M.J.; MOOCHHALA, S.H.; BARBOUR, J.; KELLY, C.A. Influence of diabetes on peripheral bone mineral density in men: a controlled study. Acta Diabetol., v.42, n.2, p.82-86, 2005.

CAY, M.; NAZIROGLU, M.; SIMSEK, H.; AYDILEK, N.; AKSAKAL, M.; DEMIRCI, M. Effects of intraperitoneally administered vitamin $C$ on antioxidative defense mechanism in rats with diabetes induced by streptozotocin. Res. Exp. Med., v.200, n.3, p.205-213, 2001.

ÇINAR, M.G.; ULKER, S.; ALPER, G.; EVINÇ, A. Effect of dietary vitamin $\mathrm{E}$ supplementation on vascular reactivity of thoracic aorta in streptozotocin-diabetic rats. Pharmacology, v.62, p.56-64, 2001.

DAMASCENO, D.C.; VOLPATO, G.T.; CALDRON, I.M.P.; RUDGE, M.V.C. Oxidative stress and diabetes in pregnant rats. Anim. Reprod. Sci., v.72, n.3-4, p.235-244, 2002.

DING, K.; WANG, Z.; HAMRICK, M.W.; DENG, Z.; ZHOU, L.; KANG, B.; YAN, S.; SHE, J.; STERN, D.M.; ISALES, C.M.; MI, Q. Disorder osteoclast formation in RAGEdeficient mouse establishes an essential role for RAGE in diabetes related bone loss. Biochem. Biophys. Res. Commun., v.340, n.4, p.1091-1097, 2006.

DUARTE, V.M.G.; RAMOS, A.M.O.; REZENDE, L.A.; MACEDO, U.B.O.; BRANDÃO-NETO, J.; ALMEIDA, M.G.; REZENDE, A.A. Osteopenia: a bone disorder associated with diabetes mellitus. J. Bone Miner. Metab., v.23, n.1, p.58-68, 2005.

FERRARI, S.; RIZZOLI, R. Gene variants for osteoporosis and their pleiotropic effects in aging. Mol. Aspects. Med., v.26, n.3, p.145-167, 2005. 
FUKUHARU, M.; SATO, J.; OHSAWA, I.; OSHIDA, Y.; NAGASAKI, M.; NAKAI, N.; SHIMOMURA, Y.; HATTORI, M.; TOKUDOME, S.; SATO, Y. Additive effects of estrogen deficiency and diabetes on bone mineral density in rats. Diabetes Res. Clin. Prac., v.48, n.1, p.1-8, 2000 .

GODSLAND, I.F. Oestrogens and insulin secretion. Diabetologia, v.48, n.11, p.2213-2220, 2005.

HADJIDAKIS, D.J.; RAPTIS, A.E.; SFAKIANAKIS, M.; MYLONAKIS, A.; RAPTIS, S.A. Bone mineral density of both genders in Type 1 diabetes according to bone composition. J. Diabetes Complicat., v.20, n.5, p.302-307, 2006.

HAMADA, Y.; KITAZAWA, S.; KITAZAWA, R.; FUJII, H.; KASUGA, M.; FUKAGAWA, M. Histomorphometric analysis of diabetic osteopenia in streptozotocin-induced diabetic mice: A possible role of oxidative stress. Bone, v.40, n.5, p.1408-1414, 2007.

ISOMURA, H.; FUJIE, K.; SHIBATA, K.; INOUE, N.; LIZUKA, T.; TAKEBE, G.; TAKAHASHI, K.; ISHIHIRA, J.; IZUMI, H.; SAKAMOTO, W. Bone metabolism and oxidative stress in postmenopausal rats with iron overload. Toxicology, v.197, n.2, p.93-100, 2004.

JANSSENS, K.; DIJKE, P.T.; JANSSENS, S.; HUL, W.V. Transforming growth factor - $\beta 1$ to the bone. Endocr. Rev., v.26, n.6, p.743-774, 2005.

KEARNS, A.E.; KHOSLA, S.; KOSTENUIK, P.J. Receptor activator of nuclear factor $\mathrm{b}$ ligand and osteoprotegerin regulation of bone remodeling in health and disease. Endocr. Rev., v.29, n.2, p.155-192, 2008.

KEMINK, S.A.G.; HERMUS, A.R.M.M.; SWINKELS, L.M.J.W.; LUTTERMAN, J.A.; SMALS, A.G.H. Osteopenia in insulin-dependent diabetes mellitus: prevalence and aspects of pathophysiology. J. Endocrinol. Invest., v.23, n.5, p.295-303, 2000.

KUME, S.; KATO, S.; YAMAGISHI, S.; INAGAKI, Y.; UEDA, S.; ARIMA, N.; OKAWA, T.; KOJIRO, M.; NAGATA, $\mathrm{K}$. Advanced glycation end-products attenuate human mesenchymal stem cell and prevent cognate differentiation into adipose tissue, cartilage and bone. J. Bone Miner. Metab., v.20, n.9, p.1647-1658, 2005.
LÉGER, J.; MARNOVIC, D.; ALBERTI, C.; DORGERET, S.; CHEVENNE, D.; MARCHAL, C.L.; TUBIANA - RUFI, N; SEBAG, G.; CZERNICHOW, P. Lower bone mineral content in children with type 1 diabetes mellitus is linked to female sex, low IGFI levels and high insulin requirement. J. Clin. Endocrinol. Metab., v.91, n.10, p.3947-3953, 2006.

LUND, K.J. Menopause and the menopausal transition. Med. Clin. North Am., v.92, n.5, p.1253 -1271, 2008.

MARTÍN-GALLÁN, P.; CARRASCOSA, A.; GUSSINYE, M.; DOMÍNGUEZ, C. Biomarkers of diabetes-associated oxidative stress and antioxidant status in young diabetic patients with or without subclinical complications. Free Radic. Biol. Med., v.34, n.12, p.1563-1574, 2003.

MARTINS, R.R; PEREIRA, N.M.L.; SILVA, T.M.A. Liquidbase cytology: a new method for oestral cycle study in wistar's rats. Acta Cir Bras, v.20, suppl.1, p.46-49, 2005.

MCCABE, L.R. Understanding the pathology and mechanisms of type I diabetic bone loss. J. Cell Biochem., v.102, n.6, p.1343-1357, 2007.

MUTHUSAMI, S.; RAMACHANDRAN, I.; MUTHUSAMY, B.; VASUDEVAN, G.; PRABHU, V.; SUBRAMANIAM, V.; JAGADEESAN, A.; NARASIMHAN, S. Ovariectomy induces oxidative stress and impairs bone antioxidant system in adult rats. Clin. Chim. Acta., v.360, n.1-2, p.81$86,2005$.

NATIONAL RESEARCH COUNCIL. Guide for the care and use of laboratory animals. Washington: Natl Academy Press, 1996. p.140.

OHKUWA, T.; SATO, Y.; NAOI, M. Hydroxil radical formation in diabetic rats induced by streptozotocin. Life Sci, v.56, n.21, p.1789-1798, 1995.

OYAMA, T.; MIYASITA, Y.; WATANABE, H.; SHIRAI, K. The role of polyol pathway in high glucose induced endothelial cell damages. Diabetes Res. Clin. Pract., v.73, n.3, p.227234, 2006.

PAPANICOLAOU, G.N. The sexual cycle in the human female as revealed by vaginal smears. Am. J. Anat., v.52, n.3, p.519-637, 1933. 
RAHIMI, R.; NIKFAR, S.; LARIJANI, B.; ABDOLLAHI, M. A review on the role of antioxidants in the management of diabetes and its complications. Biomed. Pharmacother., v.59, n.7, p.365-373, 2005.

RASMUSSE, L.M.; TARNOW, L.; HANSEN, T.K.; PARVING, H.H.; FLYVBJERG, A. Plasma osteoprotegerin levels are associated with glycaemic status, systolic blood pressure, kidney function and cardiovascular morbidity in type 1 diabetic patients. Eur. J. Endocrinol., v.154, n.1, p.75-81, 2006.

REDDY, G.K.; STEHNO-BITTEL, L.; HAMADE, S.; ENWEMEKA, C.S. The biochemical integrity of bone in experimental diabetes. Diabetes Res. Clin. Pract., v.54, n.1, p.1-8, 2001 .

RHO. J.; TAKAMI, M.; CHOI, Y. Osteoimmunology: interactions of the immune and skeletal systems. Mol. Cells, v.17, n.1, p.1-9, 2004.

RIO, D.D.; STEWART, A.J.; PELLEGRINI, N. A review of recent studies on malondialdehyde as toxic molecule and biological marker of oxidative stress. Nutr. Metab. Cardiovas. Dis., v.15, n.4, p.316-328, 2005.

SANTOS, M.; DUARTE, M.; MATOS, M.; PROENÇA, T.; SEIÇA, R.; OLIVEIRA, C. Synaptosomes isolated from Goto-Kakizaki diabetic rat brain exhibit increased resistance to oxidative stress: role of vitamin E. Life Sci., v.67, n.25, p.3061-3073, 2000.

STOPPA, G.R.; CESQUINI, M.; ROMAM, E.A.F.R.; OGO, S.H.; TOSONI, M.A. Aminoguanidine prevented impairment of blood antioxidant system in insulindependent diabetic rats. Life Sci., v.78, n.12, p.1352-1361, 2006.

SUZUKI, K.; KUROSE, T.; TAKIZAWA, M.; MARUYAMA, M.; USHIKAWA, K.; KIKUYAMA, M.; SUGIMOTO, C.; SEINO, Y.; NAGAMATSU, S.; ISHIDA, H. Osteoclastic function is accelerated in male patients with type 2 diabetes mellitus: the preventive role of osteoclastogenesis inhibitory factor/osteoprotegerin (OCIF/OPG) on the decrease of bone mineral density. Diabetes Res. Clin. Prac., v.68, n.2, p.117-125, 2004.
TAN, K.C.B.; CHOW, W.S.; TAM, S.; BUCALA, R.; BETTERDGE, J. Association between acute-phase reactants and advanced glycation end products in type 2 diabetes. Diabetes Care, v.27, n.1, p.223-228, 2004.

THRAILKILL, K.M.; LIU, L.; WAHL, E.C.; BUNN, R.C.; PERRIEN, D.S.; COCKRELL, G.E.; SKINNER R.A.; HOGUE, W.R.; CARVER, A.A.; FOWLKES, J.L.; ARONSON, J.; LUMPKIN JR, C.K. Bone Formation Is Impaired in a Model of Type 1 Diabetes. Diabetes, v.54, n.10, p.2875-2881, 2005a.

THRAILKILL, K.M.; LUMPKIN, C.K.; BUNN, R.C.; KEMP, S.F.; FOWLKES, J.L. Is insulin an anabolic agent in bone? Dissecting the diabetic bone for clues. Am. J. Physiol. Endocrinol. Metab., v.289, n.5, p.E735-E745, 2005 b.

VALKO, M.; LEIBFRITZ, D.; MONCOL, J.; CRONIN, M.T.D.; MAZUR, M.; TELSER, J. Free radicals and antioxidants in normal physiological functions and human disease. Int. J. Biochem. Cell Biol., v.39, n.1, p.44-84, 2007.

WADA, T.; NAKASHIMA, T.; HIROSHI, N.; PENNINGER, J.M. RANKL-RANK signaling in osteoclastogenesis and bone disease. Trends Mol. Med., v.12, n.1, p.17-25, 2006.

WORLD HEALTH ORGANIZATION. Scientific Group on Research on the Menopause in the 1990s. Geneva: WHO, 1996. 114 p. (WHO Technical Report Series n.866).

YAMAGISHI, S.; NAKAMURA, K.; INOUE, H. Possible participation of advanced glycation end products in the pathogenesis of osteoporosis in diabetic patients. Med. Hypotheses, v.65, n.6, p.1013-1015, 2005.

Received for publication on $04^{\text {th }}$ June 2009 Accepted for publication on $03^{\text {rd }}$ March 2010 